\title{
The Tortuous Path to a New Economic Agenda in Egypt and Tunisia
}

\author{
By Karen Pfeifer ${ }^{*}$
}

Three overarching features characterize the recent economic evolution of Egypt and Tunisia. First, they were the celebrated macroeconomic "success stories" of neoliberalism in the Arab Mediterranean and participated fully in the worldwide economic boom of the 2000-2008 period. Second, the accompanying spread of negative features ultimately underpinned the uprisings of 2010-2011, including unemployment, especially among educated youth, poverty, especially in the neglected hinterlands, expanding informal sectors, corruption and cronyism, electoral fraud, and repression of labor, civil society organizations and political opposition. Third, as of March 2014, none of the governments that followed the ousting of the Mubarak and Ben Ali regimes had presented a coherent program for more equitable and sustainable economic transformation, while political turmoil, violence - two political assassinations in Tunisia and the overthrow of the elected president in Egypt -- and instability prevailed. Aside from the perpetuation of stagnation in an atmosphere of mistrust and uncertainty, there was a spectrum of possible approaches for economic transformation. From "right to left" these included (1) neoliberalism with an inclusive mask, as promoted by the IFIs and Deauville Partnership, (2) a developmental state and industrial policy in the East Asian mode, (3) a more egalitarian developmental state as proposed by the United Nations Development Program (UNDP) and International Labor Organization (ILO), and (4) a citizen-led developmental state as encoded in the work of NGOs and the independent trade union movement.

\section{The State of the Egyptian and Tunisian Economies at Start of 2014}

During the three years following the uprisings that removed Zine AlAbedine Ben Ali and Hosni Mubarak from power, Tunisia and Egypt witnessed very slow formal economic growth, rising unemployment, much reduced tourism, shrinking foreign direct investment and continued (mostly illegitimate) outflows of domestic capital. Despite the heroic inflows of remittances from citizens working abroad to support their families, both countries faced deterioration in their national budgets, with rising deficits and

${ }^{*}$ Professor Emerita of Economics, Smith College, USA.

https://doi.org/10.30958/ajms.1-1-1

doi=10.30958/ajms.1-1-1 
government borrowing, and in their current accounts and foreign exchange reserves, the latter needed to purchase essential imports. Broad and repeated waves of labor unrest broadcast popular discontent with the lack of economic progress.

The causes are a complex interplay of factors, including the political uncertainty of the halting "transition" to full democratic institutions and the social uncertainty of the role of Islamism in defining the emerging polities. Furthermore, the world economy and particularly the economy of Europe, a main source of tourism, trade and foreign direct investment, and a main host of émigré labor, were still in the doldrums five years after the global financial crisis. This paper deals with internal economic uncertainty, namely the as-yet unmet need for a clear, coherent and comprehensive program for equitable and sustainable development, and the varied approaches to economic restoration.

\section{The IFIs' Approach through 2010: Neoliberal Reform}

Egypt and Tunisia were the vaunted success stories of neoliberal reform in the Arab World from the 1990s through 2010. They were praised both for the policy changes they undertook under the guidance of the International Monetary Fund and the World Bank (the international financial institutions, or IFIs), aid agencies such as USAID, and the European Union's Mediterranean Partnership Agreements, and for the outcomes attributed to those policies (e.g., IMF 2007a: 3; IMF 2007b:3).

While these economies survived the financial crisis and recession relatively well due to effective Keynesian macropolicy, the IFIs continued to admonish their governments for delays in further liberalization and privatization. Defects such as corruption and cronyism, along with labor protections and consumption subsidies, were seen by the IFIs as flaws internal to the culture or as benighted holdovers from the statist era (e.g., IMF 2010a: 3; IMF 2010b: 3). While the IFIs took credit for the macroeconomic successes of Egypt and Tunisia up to 2008, they admitted no responsibility for the negative socio-economic features of neoliberal transformation or the corrosive political features of these autocracies.

\section{Growing Doubts about the Ideas, Policies and Outcomes of Neoliberalism}

Dissenters from the neoliberal agenda had been raising their concerns elsewhere since the 1990s, but dissenters among Middle Eastern economists did not emerge from the shadows until the mid-2000s. A growing body of research uncovered the negative features of neoliberal transformation. These included: "high and persistent unemployment" despite economic growth, growing pressure on the young to migrate for work, the relation between neoliberal "reform" and the authoritarian state, the growth of corruption and 
informality and the relation between them, capital flight, the limited contribution of bilateral trade with and FDI from Europe to domestic interindustry linkages, growing interregional disparities related to both public investment decisions and the concentration of FDI in the more developed areas, and the neglect of agriculture alongside misbegotten programs to shift agriculture from production for the domestic market toward production for export. ${ }^{1}$

The second form of dissent was a reconsideration of the role of the state and alternative economic strategies. A "Cairo Consensus" was offered by 600 conference delegates in 2003 postulating, first, that increased integration in the world economy was necessary to avoid marginalization and reduce inequality among countries, but, second, that policies must be adapted to local conditions in order to minimize the negative effects of globalization (Dinello \& Squire 2005: xii-xiii). As one Arab delegate explained, the poor benefited only half as much as the non-poor when growth accelerated, so, "Policymakers need to forge a domestic growth strategy, relying on domestic investors and domestic institutions" to resolve conflicts arising from increased integration with the world economy (Ali 2005: 60).

The idea that Middle Eastern countries could benefit from adopting policies more like those of the East Asian countries percolated up through hegemonic neoliberal orthodoxy. The Egyptian Competitiveness Report of 2006 credited improvements in Egypt's rankings to neoliberal policy changes, but observed that other indicators worsened, like Egypt's debt to GDP ratio, or improved too slowly, like health and primary education, market efficiency, and innovation. The report endorsed "an appropriate industrial strategy" with "a comprehensive set of policies." Some scholars argued that the explanation for Tunisia's relative success as a beacon of economic and social progress in the Arab World lay not in its shift toward neoliberalism but rather in its unique application of the East Asian state-led model of development and gradual, controlled reform (Cammett 2007; Harrigan \& El-Said 2010).

The appointment of Ahmed Galal as Managing Director of $\mathrm{ERF}^{3}$ in 2007 seemed to open up the discussion to more of these challenging questions. Some of Galal's work had been on industrial policy and the relevance of the East Asian state-led development model to the Arab World (Galal 2008, 1998). He had been the executive director of the Egyptian Center for Economic Studies, a think tank for Egyptian economists endorsed by Gamal Mubarak and a number of business leaders in an apparent effort to adjust public policy to overcome some of the negative aspects of neoliberalism.

\footnotetext{
${ }^{1}$ Sample of papers available upon request.

${ }^{2}$ http://www.encc.org.eg/inside.php?p=temp list\&pid=102

${ }^{3}$ Economic Research Forum for the Arab States, Iran and Turkey.
} 


\section{IFI Efforts to Control Knowledge Production on Arab Spring}

Some flies in the IFIs' ointment appeared in the organizations' own research prior to 2010, such as the unimpressive performance of the Social Development Fund, which had been introduced in Egypt in 1991 in conjunction with the Economic Reform and Structural Adjustment Program (ERSAP) to cushion the impact of neoliberal reform on the poor (World Bank 2009). However, it was not until after the uprisings that the IFIs published a raft of research papers and whole volumes defining the problems that had led to the Arab Spring. The IFIs' capture of the "critique" process could be used to absolve neoliberal programs from responsibility and, then, to redirect attention to "solutions" that conformed to their essentially unchanged agenda.

In Egypt, Bank researchers found that, in an era of high economic growth, 'between 2004/2005 and 2008/2009, extreme poverty and absolute poverty actually increased,' leaving about two-fifths of the population 'poor or near poor' (World Bank 2011). A second study traced the main causes of poverty to urban-rural disparities and women's low labor force participation, the solution being to target the needy as general subsidies were reduced (World Bank 2012a). Finding deeply uneven development among Egypt's governorates, another study recommended unifying the domestic market of the country to encourage more factor mobility (World Bank 2012b). When a different study found that internal migration in Egypt was low by international standards, the authors recommended improving the material incentives to migrate and targeting subsidies to those left behind (Herera and Badr 2012: 3). The possibility of raising agricultural wages and producer prices was not mentioned.

Similarly, a semi-independent audit of the World Bank's 7-year, \$23.7 million program to reshape Tunisian agriculture, shifting "from an emphasis on food self- sufficiency and production for the domestic market to increasing integration in the world market," gave it a performance grade of "moderately unsatisfactory' (World Bank 2013: x-ix). When sharp regional disparities, in levels of infrastructure and private investment, employment, literacy, healthcare and other public services, were discovered between the "two Tunisia's," that is, the relatively affluent coastal regions versus the lagging interior regions, " the African Development Bank and USAid announced a bold new model to promote small and medium enterprises (SMEs) in the lagging regions (AfDB et al. 2013).

Discovering that, after twenty years of liberal reforms, Egypt and Tunisia had large informal sectors by every measure: respectively, 36 and 39 percent of GDP, 28 and 25 percent self-employed as proportion of total employment, and 45 and 50 percent of the labor force not contributing to social security (Gatti 2011: 8, Figure 3), Bank researchers recommended promoting the private sector and providing incentives (such as lower taxes and subsidies for social security payments) to induce informal business to join the formal sector. While

${ }^{1}$ Robert Joyce, “Three Years Later, Tunisia's Interior Still Neglected," www.tunisia-live.net/ 2013/12/24, citing World Bank \& African Development Bank reports from 2011. 
targeting the rural poor with job training, they advised relaxing labor regulations (such as severance pay in Egypt and centralized wage bargaining in Tunisia) and otherwise reducing the benefits of working in the public sector (Gatti 2011: 25).

Another strand of research exposed the crony capitalism and kleptocratic features of the pre-uprising regimes, recommending optimal regulation and application of the rule of law, as the IFIs define them, to prevent this kind of "state capture" in future (Chekir and Diwan 2013; Rijkers et al 2014).

Such research and recommendations formed the basis of the allegedly new approach of the IFIs to the emerging governments of what they christened the "Arab Countries in Transition" (ACTs) after the Arab Spring.

\section{Approach 1: Deauville's Neoliberalism with an Inclusive Mask}

The international financial institutions, the G8, the dominant economic powers in the GCC and "donor" agencies gathered together at Deauville France, in May 2011 to set out a common agenda "to support the historic political and economic transformation under way in the Middle East and North Africa" (Chauffour 2013: 1). ${ }^{1}$ Scrambling to get ahead of the curve of the "transition," and fearful of the populace's mistrust of their programs, these patrons of best practice urged their clients to "take the long view" and not succumb to popular pressures (World Bank and IFC 2012a; 2012b.) The only path to productivity growth and job creation was not to be the difficult route of Arabs inventing new technology themselves, but by "the much more manageable task" of catching up to existing standards and knowledge through transfer from international trading partners and investors (Chauffour 2013: 12).

The proposed reforms to overcome the ACTs' "important structural challenges" and "long-running structural deficiencies" (IMF 2012b) were the same as they had been for 30 years: cut government spending and raise taxes, promote the private sector for job creation, especially small and medium enterprises, streamline business regulation, reduce labor market "rigidities," and restructure the education system to match skills with private employers' needs. Furthermore, to transform themselves into knowledge economies, the ACTs were instructed to reform university education "in partnership with prestigious foreign institutions" and integrate with the EU (World Bank 2013a: Xvi-xviii). Each individual ACT was offered specific advice and assured that loans would be available to finance projects run by the IFC in partnership with local organizations, while teams of Bank and Fund advisers monitored their "progress."

\footnotetext{
${ }^{1}$ The partners are the G8, namely Canada, France, Germany, Italy, Japan, Russia, the United Kingdom, and the United States, plus regional economic powers Turkey and GCC members Kuwait, Qatar, Saudi Arabia and the United Arab Emirates, in company with nine international and regional financial institutions (Chaffour 2013: 1).
} 
These keys to growth were held by the same cast of characters that led the world into the financial crisis of 2008 and the Great Stagnation of 2009-2013, and who are still struggling to recover (World Bank 2014: 15). Meanwhile, the IFIs take no responsibility for problems that emerged in the neoliberal era, saying, "In most Arab countries, it has become evident that the development paradigm of the past cannot achieve the qualitative and inclusive growth expected by the population" (Chauffour 2013: 1). Yet the Deauville Partners include four Gulf monarchies where the state-dominated, non-democratic "development paradigm of the past" goes on unchallenged, sustained by hydrocarbon revenues that endow them with the financial power to influence the transition agenda for the struggling republics.

\section{Approach 2: East-Asian-Style State-Led Development}

Tunisia under Bourguiba and Ben Ali, despite kleptocratic features, took the lead in pursuing an East-Asian-style state-led growth model. However, the transitional Tunisian government as of early 2014 was in a quandary as to how to proceed. On one hand, the IFIs seemed to have the upper hand in pressing conditions for "reform," given the bedraggled state of the economy and the dearth of foreign exchange, while President Mehdi Joma a made the rounds to the wealthy Gulf countries and the United States appealing for support. On the other hand, there was strong pressure from NGOs and popular movements, especially labor, to resist austerity and to push for economic as well as political democracy.

In Egypt, ECES economists and their business supporters had worked toward reforming the economy with "a muscular liberalism that requires a powerful and invasive state. But this invasiveness is targeted and constrained" (Rutherford 2008: 218). Their various proposals prior to the uprising included regulation of markets to preserve competition and prevent corruption, a unified tax code, monitoring of the financial industry, enforcement of contracts, protection of private property, and timely dispute resolution. This approach would increase spending on social services like education, healthcare, job training, unemployment insurance and pensions, in order to improve the quality and mobility of labor force, but the private capitalist sector would play an important role in a national health insurance program and a reformed educational system. Broad subsidies for food and fuel would be eliminated in favor of targeting special subsidies to only the most needy. Trade liberalization would continue and be facilitated by a simplified customs code, while international exposure of civil violations would help press for the rule of law (Rutherford 2008: 211-222).

Egypt's earlier experience with a state-led model had had mixed results. While the 1960s had witnessed development of an industrial base and "left a legacy of local know-how and physical infrastructure," the manufacturing sector had become less diverse from 1980 to 2000 and productivity growth was low, especially in protected activities. Based on the comparison with East Asia, 
ECES researchers advocated a reformed industrial policy to restructure important but lagging industries like textiles, offering time-limited tax incentives to firms for measurable outcomes like job creation and export success, and encouraging SMEs and innovative new sectors (Galal and ElMegharbel 2008: 20-21; Rutherford 2008: 211-222). However, citizens and workers seemingly were to play a passive role in this scenario.

In August 2012, during the Morsi presidency, an ECES policy paper suggested a program for the government to pursue in the name of "inclusive growth," but again left citizens as passive players. The proposals "build on previous ECES research to address distortions that have built over the past 6 decades, adversely impacting economic management and performance... [and] aim to articulate priorities for the economic reform agenda and help guide policies in the future" (Kandil 2012: 1). Removing impediments to private business was the overarching objective, for which the top priority was reducing uncertainty and establishing political stability and security.

The first five specific pillars of the program were standard neoliberal reforms, while the remaining items addressed issues raised by the uprising. They included reducing poverty and inequality by (a) reducing fuel subsidies, while sheltering public services such as transportation from price inflation, and gradually eliminating generalized food subsidies in favor of either cash or inkind direct transfers to the poor, (b) creating jobs through restoring laborintensive tourism and promoting SMEs, and (c) inducing the informal sectors to join the formal sector -- by reducing costs and taxes for employers and increasing incentives through credit access and social insurance, relaxing labor laws, and upgrading job quality -- and reforming education to teach technical and managerial skills needed by private employers. Unless they were entrepreneurs, citizens were to play a passive role in this scenario too.

After the ousting of elected President Mohammed Mursi in July of 2013, President Adly Mansour named a cabinet led by economists, including Prime Minister Hazem Beblawi and Finance Minister Ahmed Galal. While the Beblawi government made efforts to begin the state-led transformation based on ECES elements, they, like the transitional coalition government in Tunisia, seemed unable to pursue a comprehensive program that would address the economic problems raised by the uprising. Neither the now-defunct Beblawiled government nor its successor, led by Ibrahim Mehleb, was receptive to the views of citizen and labor groups. As of April 2014, presidential candidate Abdel Fattah Al-Sisi had not offered an economic program, save to engage Saudi, Kuwait and Emirati donors and investors in partnership projects with the military.

\section{Approach 3: UNDP and ILO Proposals for State-Led Development}

After 20 years of publishing the Human Development Report as an antidote to the neoliberal approach, and almost a decade of publishing the Arab Human Development Report, the UNDP team for the Arab states, based in 
Cairo, responded to the Arab uprisings by offering an alternative approach to a regionally-adapted developmental state (UNDP 2011: 1-6).

The UNDP approach broadened and sometimes contradicted the top-down developmental state, as it was premised on the transition to a democratic system with "good governance" requiring the state to be responsive and accountable to an active and watchful citizenry. The model recommended industrial policy to promote complementary public investment in infrastructure and productive private investment across sectors, including agriculture, to break out of the rentier economy trap in which virtually all Arab economies were ensnared, including Egypt and Tunisia (UNDP 2011: 6-7). It called for stronger regional economic integration among equal partners, not between powerful investors/donors on one hand and supplicants on the other, to enable the region to participate in the global economy from a position of internal diversification and common strength.

New rules of the game would guide the actors in domestic development. Private investment and job-creation would be essential, but the social contract would require that firms pay taxes and "ensure decent working conditions" (UNDP 2011: iv). Increased government revenue would come from progressive income, property and capital gains taxes, while domestic investment would be guided geographically to lagging regions and to jobcreating enterprises. In this analysis, unemployment was primarily a demandside problem due to the previous twenty-year trajectory of capital-intensive and non-productive investment, e.g., FDI in hydrocarbons and in luxury real estate and retail (UNDP 2011: 5-13).

The International Labor Organization (ILO 2012, 2011) proposed complementary programs that would retain those neoliberal reforms that encouraged an innovative private sector, especially SMEs, and that brought in productive foreign investment, but with institutional protections for workers, the environment, and the domestic economy. It would explicitly require full labor representation in making those policies, in the context of social dialogue among all groups of actors to negotiate differences. The ILO officially endorsed labor laws protecting essential rights to assemble freely, to organize independent unions and elect union leaders without state or employer interference, to bargain collectively over wages, benefits and working conditions, and to strike without penalty when negotiations were stymied. The fullest version would include universal health insurance, a universal pension plan, unemployment insurance and a minimum wage high enough to keep fulltime workers out of poverty.

In addition, the ILO argued for active labor market policies (ALMPs), including public investment programs to generate new jobs in building infrastructure and running expanded educational and health services. Its proposed ALMPS would include agencies to train employers, for example in how to raise workers' morale and productivity, as well as to train potential employees in the professional and social skills they need to get and hold jobs, and to do active matching of employers and employees. Proposals included restructuring of the safety net to guarantee a livable income for both the 
unemployed and those who do not earn enough to support their families, in addition to absorbing workers from the informal sector by raising wages, improving the quality of jobs and terms of employment, and subsidizing the extension of social protections (ILO 2012, Chap 7, "Workers' Perspective.")

The proposals of the UNDP and ILO presumed that growth with equity, poverty reduction, diversification and even food security could be realized without dispensing with the capitalist system. However, in this author's opinion, such programs could only come into being if the governments of the Arab Spring countries were responsive to organized political pressure from social democratic movements representing the interests of the middle class, workers and farmers, perhaps in alliance with far-sighted capitalists and entrepreneurs.

\section{Approach 4: Proposals from NGOs, Labor and Progressive Economists}

The social democratic approach was articulated by the NGOs, economists in academic and media roles, and independent trade unionists who spoke on behalf of the non-elite classes in pre- and post-uprising Tunisia and Egypt. This articulation incorporated many of the state-led development proposals as delineated above, but reached deeper into reforms addressing "social justice." A major limitation as of March 2014 was that these proposals had not been brought together as mutually reinforcing planks in a coherent, comprehensive economic platform that could serve a broad-based political formation with public presence. Both Tunisia and Egypt were scheduled to have presidential and parliamentary elections in 2014. However, while political stability and reduced uncertainty were secured through peaceful compromise in Tunisia among established political forces, stability was imposed by the restoration of authoritarian rule in Egypt, where repression of dissent and social conflict were more overt.

Examples of extensive and detailed proposals from these groups included confronting the national debt and foreign capital, budget transparency and management, "green development," unemployment, welfare and human development, and the rights of labor.

As the Deauville partners imposed conditions for further austerity in exchange for their financial favors, popular resistance stiffened against both austerity and the concomitant and perpetual indebtedness that the neoliberal bargain entailed. Activists in Tunisia and Egypt argued for the cancellation of the "odious" portion of the debt incurred by the Ben Ali and Mubarak governments, funds used for the purchase of "security" equipment, for example, or for the personal enrichment of the regime and its cronies. ${ }^{1}$

\footnotetext{
${ }^{1}$ http://www.jadaliyya.com/pages/index/2979/we-will-not-pay-the-debts-of-tyranny (retrieved 22 jun 2013); http://humanrightshouse.org/Articles/17846.html (retrieved 10nov2013); http://www.th etunistimes.com/2013/11/campaign-to-cancel-the-odious-debt-of-tunisia-and-egypt-99653/ (retrieved 12nov2013); http://www.fsm2013.org/en
} 
Cancellation of this part of the debt would reduce the debt servicing which ate up a significant part of the annual budget and contributed to fiscal and current account deficits.

An alternative to outright debt forgiveness was to turn the debt into aid for development projects or even a "Marshall Plan" focusing on domestic development, especially agriculture. ${ }^{1}$ Proposals to promote agriculture in Tunisia, and especially farmers' rights, food security, and programs tailored to local needs, have come from critics of World Bank programs there, where development loans were wasted (Gana 2012), as well as from Tunisian labor and NGOs. In Egypt, debt-forgiven aid could be used to fund development banks for lagging regions, lending, for example, to SMES that create decent jobs and respect labor rights, or producer cooperatives to help organize the informal sector. Negotiating fair trade and FDI that contribute to domestic economic development, as well as capital controls and institutional prevention of capital flight, would also promote more equitable and sustainable development.

A number of proposals addressed budget issues. An overarching demand was for total transparency in both current and developmental budgeting. All components of and background documents to the budget construction process would be available free of charge on the Web, and composed so that they could be understood and monitored by the public. Although the IFIs claim to promote transparency and accountability in governance and claim to consult with civil society, they still negotiated with post-uprising governments behind closed doors.

In Egypt, proponents used exacting calculations to argue that it was not necessary to borrow abroad, because the required resources were available domestically, with properly structured income and financial-transaction taxation and, for example, renegotiating corrupt Mubarak-era contracts with oil and gas exporters and with international customers. Savings on the expenditure side could be obtained from reducing or eliminating subsidies to privileged firms, including luxury tourist resorts, real estate developers, and domestic and foreign firms in the cement, fertilizer, iron and steel, ceramics and aluminum industries and conversion of bakeries and brick kilns, transport vehicles and microbuses to natural gas engines. ${ }^{2}$

Other NGO proposals for Egypt arose out of critiques of the impact of World Bank and other IFI-led projects on the 'built environment,' and out of government plans for 'urban development' that privileged a few wealthy investors over the current inhabitants, even when the latter had clear legal title. The alternative proposals promoted environmentally sound, affordable housing and public infrastructure that would allow communities to stay intact with

\footnotetext{
${ }^{1}$ Aziz el Yaakoubi, "Tunisia Seeks Next IMF Tranche as Spending Cuts Spark Protests," www.reuters.com, 8 Jan 2014; Luciana Borsatti, "Tunisia: MP Moussa, Europe Should Do More," www.ansamed.info, 21 March 2014.

${ }^{2}$ Mossallem 2013; Rowden 2013; Gamal 2013; An-Naggar 2013
} 
better public services, as well as increased investment in green energy, in which Egypt has a strong comparative advantage. ${ }^{1}$

Other proposals specifically tailored to Tunisia tackled the unruly problems of unemployment and uneven regional development. One economist proposed an Employer of Last Resort (ELR) program, using the country's preexisting 'Solidarity Network' of small-scale bank lending and the national Solidarity and Employment Funds. The program could create 400,000 jobs over six years, addressing unmet needs, especially in the rural areas, in fields as diverse as alternative energy, affordable housing, education and healthcare, with multiplier effects that would contribute more to economic growth than the program cost (Kaboub 2006). Another comprehensive proposal for Tunisia was an updated version of the social market economy like that developed in Sweden in the 1930s, with an enforceable and comprehensive social contract, accompanied by decentralization of administrative and fiscal responsibility (Muhanzua and Castel 2014).

Progressive NGOs in Egypt supported not only civil and human rights, as defined in international conventions and by the United Nations Development Program, most of which Egypt signed onto under Mubarak, but also labor rights as defined in International Labor Conventions including the right to work and to belong to freely chosen labor unions (for example, ECESR 2013).

An active labor movement in Tunisia engaged in numerous strikes before, during and after the uprising to protest economic conditions and public policy. However, organized labor in Tunisia had a more central and less confrontational relationship to the post-uprising government than in Egypt. The main trade union confederation, the UGTT, played a critical role in the uprisings and then joined with the main employers' organization, UTICA, and a group of opposition parties to conduct protracted and ultimately successful negotiations to persuade the elected, but unpopular, Islamist-led coalition government to step down in favor of a more socially neutral transition cabinet that could oversee the writing of a new constitution and election law in 2014.

Egypt, too, saw many large-scale waves of labor action in the years before, during and after the 2011 uprising. ${ }^{2}$ Prime Minister Ibrahim Mehleb's government was still at loggerheads with the labor movement as of March 2014. The movement's demands, some specific to particular sectors but many common to all, had been put to previous governments, starting with Mubarak, but were never satisfactorily or respectfully dealt with. Egypt's lack of a functioning freely elected national assembly to represent the disparate views of various actors in society and growing repression of the media in 2013-2014 left workers no means to influence public policy except through labor actions.

First and foremost, workers in all independent professional syndicates and labor unions demanded the passage and implementation of the long-shelved new labor law similar to what Tunisia already had. This law would recognize the right to organize in unions chosen by the workers themselves (as opposed

\footnotetext{
${ }^{1}$ Bank Information Center 2013; Shawqi Interview, 6/18/13; EIPR interviews, 6/19/13

${ }^{2}$ The following paragraphs are based on interviews held in June 2013 with Fatma Ramadan, Kamal Abou 'Aita, and leaders of trade unions in Suez.
} 
to the state-dominated monopoly of a single trade-union federation) and the right for those unions to bargain collectively. It would enforce respect for the right to strike and to engage in other forms of peaceful protest and labor action if employers refused to bargain in good faith.

Second, workers sought to improve their own economic well-being in the context of a systemic overhaul of income distribution. The first step would be a universally enforced legal minimum wage, like Tunisia's. As of March 2014, the Mehleb government had decreed a minimum gross income of LE 1200 (\$171.50) for the less than 18 percent of the labor force employed directly by the government. In addition, workers sought universal coverage for health and other forms of social insurance and pensions.

Third, workers demanded productive investment from public and private employers, the reinstatement of thousands of laid-off employees, and an active role for themselves in modernizing their industries and services to improve efficiency and increase output. This principle was applied to all sectors, including decrepit public transportation, obsolete or underutilized factories, and the resource-starved national public healthcare system.

\section{Conclusion}

Forward-looking economic agendas for Egypt and Tunisia should take account of defects that accompanied the pre-uprising development patterns, the subsequent three years of stagnation and uncertainty, and the broad-based and continuing popular movements' demands for bread, freedom and social justice that were so clearly articulated in the Arab Spring. Each of the four approaches described above has positive contributions to make to a new economic agenda, but all social actors have to be engaged either directly or through their elected representatives in its design and implementation if the promise of the Arab Spring is to be fulfilled. This would require free and fair elections for both the executive and legislative branches of government, an independent judiciary, the devolution of some resources and authority to local governments, and the essential civil freedoms of assembly and speech, including an unfettered media, and of civil society and labor rights as codified in international conventions. As of April 2014, neither country met these requirements, and Egypt was moving in the opposite direction.

The IFIs and Deauville partners could make legitimate and useful contributions to this process, but not through imposing conditions (formal or implicit) for austerity, liberalization and promotion of the private sector, which is what they were doing in the spring of 2014. Rather, what they could offer, in addition to financial support, is facilitation of rescheduling of the national debt and cancellation of its odious portions, recovery of stolen public assets, and technical advice on restructuring the tax and subsidy systems to foster true progressivity and thus more equitable post-tax-and-transfer income distribution. They could also set an example for financial transparency and accountability in their own dealings with the countries' governments. 
Given an elected government, with transparent and accountable planning and budgetary processes, the executive and legislative bodies could generate reasonable and fair indicative plans for integrated development of the industrial, agricultural, service and human-development sectors, with negotiated roles for foreign and domestic private capital. Such state-led development has been shown to work elsewhere, but in these cases, with the background of the uprisings, it is unreasonable to expect that top-down-only programs can work in the long run. The many useful programmatic suggestions put forward by the UNDP, ILO, progressive economists, and civil-society and non-governmental organizations need be taken into account in a democratic consultative process. Finally, a major key to continued long-term success would be the pro-active inclusion of organized labor in planning, policymaking and execution of negotiated sector-by-sector development programs.

\section{References}

African Development Bank, Government of Tunisia, \& Millenium Challenge Corporation (USA) 2013. Towards a New Economic Model for Tunisia: Identifying Tunisia's Binding Constraints to Broad-based Growth. [No place of publication]

Ali, Ali Abdel Gadir 2005. "Globalization and Inequality in the Arab Region." In Globalization and Equity, Perspectives from the Developing World, Natalia Dinello \& Lyn Squire, eds: 37-66. Cheltenham Glos, UK: Edward Elgar Publishing

Bank Information Center 2013. "Impact of World Bank Policy and Programs on the Built Environment in Egypt." Washington DC: Bank Information Center (lead investigator Yahya Shawkat)

Cammett, Melani 2007. "Business-Government Relations and Industrial Change: The Politics of Upgrading in Morocco and Tunisia." World Development 35 (11): 1889-1903

Chaffour, Jean-Pierre 2013. From Political to Economic Awakening in the Arab World: the Path of Economic Integration, A Trade and Foreign Direct Investment Report for the Deauville Partnership. Washington DC: The World Bank

Chekir, Hamouda and Ishac Diwan 2013. "Distressed Whales on the Nile - Egypt Capitalists in the Wake of the 2010 Revolution." Cairo: Economic Research Forum Working Paper 747

Dinello, Natalia, \& Lyn Squire, eds. 2005. Globalization and Equity, Perspectives from the Developing World. Cheltenham Glos, UK: Edward Elgar Publishing.

Egyptian Center for Economic and Social Rights 2013. "Submission to the Committee on Economic, Social and Cultural Rights, On occasion of the review of Egypt's Periodic Report...." Geneva: United Nations CESCR

Galal, Ahmed 2008. "Comparative Assessment of Industrial Policy in Selected MENA Countries: An Overview." Chap 1 in Ahmed Galal, ed., Industrial Policy in the Middle East and North Africa, Rethinking the Role of the State. Cairo: The American University in Cairo Press

1998. "Priorities for Rapid and Shared Economic Growth," Cairo: ECES Policy Viewpoint 3 
Galal, Ahmed \& Nihal El-Megharbel 2008. "Do Governments Pick Winners and Losers? An Assessment of Industrial Policy in Egypt." Chap 2 in Ahmed Galal, ed., Industrial Policy in the Middle East and North Africa, Rethinking the Role of the State. Cairo: The American University in Cairo Press

Gana, Alia 2012. "The Rural and Agricultural Roots of the Tunisian Revolution: When Food Security Matters," International Journal of Sociology of Agriculture and Food 19 (2): 201-213.

Gatti, Roberta, Diego F. Angel-Urdinola, Joana Silva, \& Andras Bodor 2011. Striving for Better Jobs, The Challenge of Informality in the Middle East and North Africa Region, Overview. Washington DC: World Bank

Harrigan, Jane R. \& Hamed El-Said 2010. "The Economic Impact of IMF and World Bank Programs in the Middle East and North Africa: A Case Study of Jordan, Egypt, Morocco and Tunisia, 1983 - 2004," Review of Middle East Economics and Finance 6 (2): 1-25

Herrera, Santiago \& Karim Badr 2012. "Internal Migration in Egypt: Levels, Determinants, Wages and Likelihood of Employment." World Bank, Policy Research Paper 6166

International Labor Organization 2012. Rethinking Economic Growth: Towards Productive and Inclusive Arab Societies. Geneva: International Labor Organization Growth. Geneva: ILO

2011. Tunisia: A New Social Contract for Fair and Equitable

International Monetary Fund 2012. Arab Countries in Transition: Economic Outlook and Key Challenges. Deauville Partnership Ministerial Meeting, Oct 12, 2012 2010a. "IMF Executive Board Concludes 2010 Article IV Consultation with the Arab Republic of Egypt," PIN No. 10/49, accompanies IMF Country Report No. 10/94, April

2010b. "IMF Executive Board Concludes 2010 Article IV Consultation with Tunisia," PIN No. 10/121, accompanies IMF Country Report No. 10/09, “Tunisia: Selected Issues," May 2007a. "Staff Report for 2007 Article IV Consultation with Arab Republic of Egypt"

2007b. "Staff Report for the 2007 Article IV Consultation with Tunisia"

Kaboub, Fadhel 2006. "A Roadmap to Full Employment and Price Stability for Developing Countries: The Case of Tunisia." University of Missouri, Kansas City: Ph.D. Dissertation

Kandil, Magda 2012. "The Egyptian Economy in Retrospect and Future Prospects," Cairo: ECES Policy Viewpoint 32

Mossallem, Mohammed 2013. "The Illusion Dispelled, Egypt's Economic Crisis: Causes-Alternatives - Remedies." Cairo: Egyptian Initiative for Personal Rights

Muhanzu, Nice \& Vincent Castel 2014. "Guided by the North Stars: No. 1 - The Swedish Model of Regional Development as a Source of Inspiration for Tunisia." African Development Bank Economic Brief

Rijkers, Bob, Caroline Freund \& Antonio Nucifora 2014. "All in the Family, State Capture in Tunisia," Washington DC: World Bank Working Papers Series 6810

Rutherford, Bruce K. 2008. Egypt after Mubarak: Liberalism, Islam and Democracy in the Arab World. Princeton NJ: Princeton University Press

United Nations Development Program (UNDP) 2011. Arab Development Challenges Report 2011: Towards the Developmental State in the Arab Region. Cairo, Egypt: Regional Center for Arab States 
World Bank 2014. Global Economic Prospects. Washington DC: World Bank 2013a. Transforming Arab Economies: Traveling the Knowledge and Innovation Road.

2013b. "Project Performance Assessment Report: Tunisia, Agricultural Support Services Project," Washington DC: World Bank, Independent Evaluation Group, Report No. 78720

2012a. Social Safety Nets in MENA

2012b. Reshaping Egypt's Economic Geography

2011. Poverty in Egypt 2008-2009.

2009. Evaluation of Social Development Fund in Egypt.

World Bank \& International Finance Corporation 2012a. Interim Strategy Note for the Republic of Tunisia for the Period FY13-14. Report no. 67692-TN. Washington DC: World Bank

2012b. Interim Strategy Note for the Arab Republic of Egypt, May 31, 2012. Report No. 66443-EG. Washington DC: World Bank

\section{Interviews conducted in Egypt in June 2013}

Al-Naggar, Ahmed Sayyed, 6/23/13, Al-Ahram News Office, Economics Research Unit, Cairo.

Abu Aita, Kamal, 6/17/13, Office of Egyptian Federation of Independent Trade Unions, Cairo

Bishara, Louis, 6/13/13, President, Bishara Textile Manufacturing (BTM), $10^{\text {th }}$ Ramadan City

ElBedrawi, Mahinour, 6/20/13, Egyptian Center for Economic \& Social Research (ECESR), Cairo

Fadel, Marian, 6/16/13. AFL-CIO Solidarity Center, Nasr City, Cairo

Gamal, Wael, 6/24/13, Groppi Restaurant, Cairo

Khalil, Heba, 6/19/13, ECESR, Cairo

Malek, Hassan, 6/19/13, Egyptian Initiative for Personal Rights (EIPR), Economic \& Social Justice Unit, Cairo

Mossallem, Mohammed, 6/19/13, EIPR, Economic \& Social Justice, Cairo

Ramadan, Fatma, 6/17/13, EIPR, Labor Rights Unit, Cairo

Shawkat, Yahia, 6/19/13, EIPR, Economic \& Social Justice Unit, Cairo

Shawqi, Baher, 6/18/13. Egyptian Ctr for Civil \& Legislative Reform, Giza

Wageeh, Tamer, 6/20/13, EIPR, Economic \& Social Justice Unit, Cairo

Representatives of unions in aluminum, ceramics, and food processing industries, and in Canal Zone Authority, 6/21/13, Suez City 
